\title{
Will Zerhouni become the new NIH director?
}

Who is Elias Zerhouni? Prior to last month, more people seemed to have heard of Keyser Söze than the Algerian-born radiologist who is reportedly the Bush Administration's favored candidate for National Institutes of Health $(\mathrm{NIH})$ director. Zerhouni's appointment will end the two-year void created by Harold Varmus' departure. However, much depends on Zerhouni's views on human embryonic stem (ES) cell research-they are not only key to his approval by the Senate, but will be equally pivotal in the future direction of the NIH, the world's largest biomedical research organization.

Zerhouni is the executive vice dean of the Johns Hopkins University School of Medicine in Baltimore, and demonstrated the administrative talent required to run NIH by being the driving force behind last year's creation of the $\$ 60$ million Institute for Cell Engineering at Hopkins.

The institute conducts cell research with the goal of turning cells into therapeutic transplants. Speaking in February 2001, Zerhouni said the use of such cells holds "enormous untapped potential to treat currently incurable diseases," and the research must be performed. "Somebody has to do it," he said. "We as an institution cannot deny to our patients the investigation of the potential of these therapies for them." A team of Hopkins scientists led by John Gearhart was among the first to create permanent stem-cell lines (Proc. Natl. Acad. Sci. USA 10, 13726; 1998).

Despite his apparent support last year for the reprogramming of human cells to yield therapeutic tissue, if appointed, Zerhouni would be expected to honor Bush's restrictions on federal funding for ES cell research and somatic cell nuclear transfer. And rumors abound within the biomedical research community that Zerhouni may have had a change of heart and may now be leaning toward a rejection of therapeutic cloning and ES cell research.

He will almost certainly face questions on these lines of study before being confirmed by the Democrat-controlled Senate, who may seek to block his appointment if they feel his views on the field will impede progress in medical research. He will first appear at hearings run by Senator Edward Kennedy (D-MA). Kennedy said he had never heard of Zerhouni until his name surfaced as a candidate.

Being pro-ES cell research is believed to have scuttled the directorship chances of

more prominent candidates such as Anthony Fauci, director of the National Institute of Allergy and Infectious Diseases, since this does not sit well with the antiabortion, pro-life Bush Administration. Fauci, in fact, was the first choice of Health and Human Services Secretary, Tommy Thompson, and his rejection is not the first time Bush has overruled the disgruntled Thompson, who is rumored to be on the verge of leaving.

With a projected FY2003 budget of $\$ 27$ billion, the degree to which NIH participates in the area of

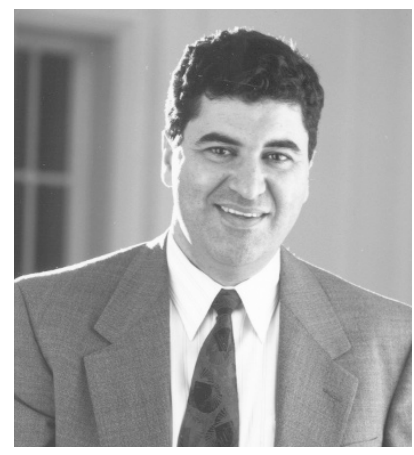

For or against ES cell research?

imaging techniques for cardiac disease. For example, he has been developing the method of magnetic resonance imaging with tissue tagging as a non-invasive technique for measuring 3-dimensional motion and deformation of the heart. One NIH scientist commented that although Zerhouni may lack detailed knowledge of the clinical trials process, "...maybe it's not a bad idea for someone to head $\mathrm{NIH}$ who has a technology focus. It would be an unusual change, possibly a positive one."'

While NIH employees called by Nature Medicine said that Zerhouni was well known to them, other scientists queried expressed some vital to international advancement of the field. "The strength of the NIH has always been derived from its focus on making investments in clear, scientifically based priorities," says Robert Schooley, an AIDS researcher who heads the division of infectious diseases at the University of Colorado Health Sciences Center. "If it strays from this, this will threaten one of the areas where the US has been pre-eminent since the end of World War II."

Former director Varmus won the 1989 Nobel Prize for discovering the cellular origin of retroviral oncogenes, and is credited with restoring NIH's basic scientific mission and putting real muscle into its research budget. Zerhouni's own research currently focuses on the development of puzzlement over his possible appointment. Schooley reflects the views of many: "He is not someone who is widely known in the biomedical research community. $\mathrm{He}$ faces big challenges, not least the fact that a large number of key positions are vacant at NIH."

Six of the NIH institutes now lack directors, including biomedical imaging, neurology, mental health, drug abuse, alcohol abuse and general medical sciences. And the Bush Administration also is grappling with other national health vacancies, including the Food and Drug Administration, Surgeon General and the Centers for Disease Control and Prevention.

Marlene Cimons, Washington, DC

\section{Poor sales trigger vaccine withdrawal}

Poor sales have prompted GlaxoSmithKline (GSK) to withdraw its Lyme disease vaccine, LYMErix, from the United States market. Lawsuits relating to adverse effects of the vaccine have been filed since its introduction, but the US Food and Drug Administration (FDA) found no proof that LYMErix is dangerous. It appears that lack of demand, not safety concerns, is the reason for the withdrawal.

Importantly, the move shows that even though the global vaccine market is expected to increase by $25 \%$ within the next five years-from a value of $\$ 4,800$ million to $\$ 6,400$ million-vaccine manufacturers are not immune to financial forces, which signals a troubled future for new vaccines against rare diseases such as West Nile virus (WNV) and Ebola if they complete development.

LYMErix was approved by the FDA at the end of 1998, and earned \$40 million in peak sales during its first year on the market. In 1999, 16,273 cases of Lyme disease, concentrated mostly in the northeastern states, were reported to the US Centers for Disease Control and Prevention (CDC). However, GSK withdrew LYMErix following predictions that less than 10,000 people would be vaccinated in 2002 .

According to a recent report by industry analyst group Datamonitor, LYMErix represented only $0.4 \%$ of the global vaccine market sales in 2000. "Companies need to 